\title{
Diabetes-induced osteoarthritis: role of hyperglycemia in joint destruction
}

\author{
Alexandrina F Mendes ${ }^{1,2^{*}}$, Susana C Rosa ${ }^{1}$, Ana T Rufino ${ }^{1}$, Madalena Ribeiro ${ }^{1,2}$, Fernando Judas ${ }^{3,4}$ \\ From Musculoskeletal Health in the 21st Century \\ Guildford, UK. 30 June - 1 July 2015
}

Recent epidemiologic and experimental data reinforced the concept that diabetes mellitus (DM) is an independent risk factor for osteoarthritis (OA). Besides a systemic inflammatory response that can affect joint tissues and contribute to OA pathogenesis, direct effects of hyperglycaemia have been shown to cause cell damage and induce inflammation by various mechanisms in several tissues associated to diabetic complications. Whether and how glucose directly affects joint tissues and cells is just beginning to be unraveled. Indirect effects of high glucose can result from enhanced formation of advanced glycation end products (AGEs) which accumulate in OA cartilage in an age-dependent manner and play a pro-inflammatory and pro-catabolic role mediated by activation of their specific receptor, RAGE, on chondrocytes and synovial cells. Some direct effects of high glucose have also been demonstrated, namely induction of IGF-1 resistance[1] and inhibition of dehydroascorbate transport which can compromise collagen synthesis[2]. Our studies have been aimed at determining whether and how hyperglycemia affects chondrocyte functions and contributes to OA development and progression. The results obtained showed that high and low glucose concentrations regulate the availability of facilitative glucose transporter (GLUT) isoforms and the glucose transport capacity of human chondrocytes. High glucose concentrations decrease the transport capacity and GLUT-1 protein content without affecting its mRNA levels, but this ability to adjust glucose transport capacity as a function of its availability is compromised in aged/OA chondrocytes leading to its intracellular accumulation[3]. The consequences of this are increased and prolonged ROS production[3] and expression of metalloproteinases (MMP)- 1 and -13[4], IL-1 $\beta$, TNF- $\alpha$, inducible nitric oxide (NO) synthase (iNOS) and NO production, mediated by high glucose-induced NF- $\kappa \mathrm{B}$ activation[5], as well as

${ }^{1}$ Faculty of Pharmacy, University of Coimbra, Coimbra, Portugal Full list of author information is available at the end of the article decreased responsiveness to TGF- $\beta[4]$ and impaired autophagy[5]. High glucose is thus sufficient to induce an inflammatory and catabolic response in human OA chondrocytes. Furthermore, it potentiates pro-inflammatory effects of IL- $1 \beta$, namely IL-6, cyclooxygenase 2 (Cox)-2, prostaglandin E2 (PGE2) and NO production[6]. The proinflammatory effects of high glucose in human chondrocytes and diabetic mice, namely induction of Cox-2, IL-6 and MMP-13 and production of PGE2, as well as decreased production of Collagen II, have also been shown to involve impairment of anti-inflammatory pathways, namely by decreasing PPAR- $\gamma$ expression[7].

Elucidating how high glucose modulates joint tissue homeostasis will identify novel targets for development of innovative strategies both to identify diagnostic and prognostic biomarkers of OA and to effectively modify disease progression.

\section{Acknowledgement \\ This work was funded by FEDER funds through the Operational Programme Competitiveness Factors - COMPETE and national funds by FCT - Foundation for Science and Technology under the strategic projects PEst-C/SAU/LA0001/ 2013 and UID/NEU/04539/2013.}

\section{Authors' details}

${ }^{1}$ Faculty of Pharmacy, University of Coimbra, Coimbra, Portugal. ${ }^{2}$ Center for Neuroscience and Cell Biology, University of Coimbra, Coimbra, Portugal. ${ }^{3}$ University and Hospital Center of Coimbra, Coimbra, Portugal. ${ }^{4}$ Faculty of Medicine, University of Coimbra, Coimbra, Portugal.

\section{Published: 1 December 2015}

\section{References}

1. Kelley KM, Johnson TR, llan J, Moskowitz RW: Glucose regulation of the IGF response system in chondrocytes: induction of an IGF-I-resistant state. Am J Physiol 1999, 276:R1164-1171.

2. McNulty AL, Stabler TV, Vail TP, McDaniel GE, Kraus VB: Dehydroascorbate transport in human chondrocytes is regulated by hypoxia and is a physiologically relevant source of ascorbic acid in the joint. Arthritis Rheum 2005, 52:2676-2685.

3. Rosa SC, Goncalves J, Judas F, Mobasheri A, Lopes C, Mendes AF: Impaired glucose transporter-1 degradation and increased glucose transport and 
oxidative stress in response to high glucose in chondrocytes from osteoarthritic versus normal human cartilage. Arthritis Res Ther 2009, 11:R80.

4. Rosa SC, Rufino AT, Judas FM, Tenreiro CM, Lopes MC, Mendes AF: Role of glucose as a modulator of anabolic and catabolic gene expression in normal and osteoarthritic human chondrocytes. J Cell Biochem 2011, 112:2813-2824.

5. Rufino AT, Ribeiro M, Judas F, Lopes MC, Mendes AF: A5.1 Culture OF human chondrocytes in high glucose induces inflammatory markers and impairs autophagy. Ann Rheum Dis 2014, 73(Suppl 1):A63.

6. Laiguillon M-C, Courties A, Houard X, Auclair M, Sautet A, Capeau J, et al: Characterization of diabetic osteoarthritic cartilage and role of high glucose environment on chondrocyte activation: toward pathophysiological delineation of diabetes mellitus-related osteoarthritis. Osteoarthritis Cartilage 2015, doi: 10.1016/j.joca.2015.04.026.

7. Chen Y-J, Chan D-C, Lan K-C, Wang C-C, Chen C-M, Chao S-C, et al: PPARY is involved in the hyperglycemia-induced inflammatory responses and collagen degradation in human chondrocytes and diabetic mouse cartilages. J Orthop Res 2015, 33:373-381.

doi:10.1186/1471-2474-16-S1-S1

Cite this article as: Mendes et al.: Diabetes-induced osteoarthritis: role of hyperglycemia in joint destruction. BMC Musculoskeletal Disorders 2015 16(Suppl 1):S1.

\section{Submit your next manuscript to BioMed Central and take full advantage of:}

- Convenient online submission

- Thorough peer review

- No space constraints or color figure charges

- Immediate publication on acceptance

- Inclusion in PubMed, CAS, Scopus and Google Scholar

- Research which is freely available for redistribution

Submit your manuscript at www.biomedcentral.com/submit 